\title{
Metabolizable energy and oil intake in brown commercial layers
}

\section{Amadeu Benedito Piozzi da Silva', Edivaldo Antonio Garcia', Andréa de Britto Molino², Elyara Maria Pereira da Silva ${ }^{3}$}

\author{
${ }^{1}$ Departamento de Produção Animal, FMVZ/UNESP - Botucatu/SP - Brasil. \\ 2 Programa de Pós Graduação, FMVZ/UNESP - Botucatu/SP - Brasil. \\ ${ }^{3}$ Departamento de Fisiologia, FZEA/USP - Pirassununga/SP - Brasil.
}

\begin{abstract}
With the objective to establish the best metabolizable energy (ME) intake for layers, and the best dietary vegetable oil addition level to optimize egg production, an experiment was carried out with 432 30-week-old Hisex Brown layers. Birds were distributed into nine treatments with six replicates of eight birds each according to a $3 \times 3$ factorial arrangement, consisting of three daily metabolizable energy intake (280, 300 or $320 \mathrm{kcal} / \mathrm{bird} /$ day) and three oil levels ( 0.00 ; 0.75 and $1.50 \mathrm{~g} / \mathrm{bird} /$ day). Daily feed intake was limited to 115,110 and $105 \mathrm{~g} / \mathrm{bird}$ in order to obtain the desired energy and oil intake in each treatment. The following parameters were evaluated: initial weight, final weight, body weight change, egg production, egg mass, feed conversion ratio per dozen eggs and per egg mass and energy conversion. There was no influence of the treatments on egg production (\%) or egg mass ( $\mathrm{g} / \mathrm{bird} /$ day). Final weight and body weight change were significantly affected by increasing energy intake. Feed conversion ratio per egg mass, feed conversion ratio per dozen eggs and energy conversion significantly worsened as a function of the increase in daily energy intake. An energy intake of $280 \mathrm{kcal} / \mathrm{bird} / \mathrm{day}$ with no addition of dietary oil does not affect layer performance.
\end{abstract}

Key Words: body weight change, egg production, lay percentage, layer nutrition

\section{Introduction}

Establishing the amount of feed intake is one of the main concerns of poultry nutritionists, considering that energy is the main factor that controls feed intake and that dietary energy represents a considerable part of costs with poultry feed (Penz Júnior \& Pavan, 2007).

According to Tardin (1995), hens are able to control their feed intake, and consequently, their energy intake to supply their requirements for the accretion of muscles, bones, and feathers, and for egg production, as well as to replace losses associated with biosynthetic processes. Harms et al. (2000) mentioned that layers can cope better with a reduction than with an increase in dietary energy.

Although some studies have demonstrated that egg production is not affected by the dietary energy content (Harms et al., 2000), Valkonen et al. (2008) obtained higher egg production in layers fed energy-rich diets, and Faria \& Silva (2004) observed that when energy intake is deficient, egg production is compromised.

Oil and fat sources have been widely used in broiler feeds to increase dietary energy density and to promote higher energy intake (Moura et al, 2003), but this practice has not been much studied in layers. According to Pinto et al. (2002), although fats increase feed palatability and reduce metabolic heat increment, feeds containing oil usually have higher metabolizable energy (ME) levels.

Costa et al. (2009) evaluated different soybean oil levels $(1,2$ and $3 \%)$ and metabolizable energy levels $(2600,2750$ and $2900 \mathrm{kcal} / \mathrm{kg}$ ) in layer diets, and observed that the lowest energy level $(2600 \mathrm{ME} / \mathrm{kg})$ promoted the best utilization of energy, and consequently, of the other dietary nutrients. Those authors verified that the inclusion of up to $3 \%$ soybean oil was not sufficient to improve energy conversions, and therefore, no significant improvement in the utilization was obtained, as shown by the lack of effect on egg production or in the weight of the egg and its components (eggshell, yolk, and albumen).

According to Pinto et al. (2002), layers subjected to high environmental temperatures reduce their feed intake, and consequently, their production performance. Those authors used different levels of soybean soapstock ( $0,1,2,3$ and $4 \%$ ) at an average temperature of $30.2{ }^{\circ} \mathrm{C}$ and observed better performance at levels of $3 \%$ and higher compared with levels of 1 and $2 \%$.

The objective of this study was to establish the best metabolizable energy intake (ME) for layers and the best level of addition of dietary vegetable oil to optimize layer performance. 


\section{Material and Methods}

In the experiment, 432 30-week-old Hisex Brown layers were distributed into 54 cages $(1.00 \mathrm{~m}$ long, $0.45 \mathrm{~m}$ deep, and $0.40 \mathrm{~m}$ high), each housing eight birds. After the peak of laying, all birds were subjected to equal management and feeding and weighed to standardize the flock.

The nine experimental treatments were distributed according to a completely randomized experimental design in a $3 \times 3$ factorial arrangement, corresponding to three ME intake levels (280, 300 and $320 \mathrm{kcal} / \mathrm{bird} /$ day) and three dietary oil levels ( $0,0.75$ and $1.5 \mathrm{~g} / \mathrm{bird} /$ day $)$, with six replicates of eight birds each. In order to obtain the desired levels of ME and oil intake, feed intake levels were limited to $115 \mathrm{~g}$ (treatments 1, 4 and 7), $110 \mathrm{~g}$ (treatments 2, 5 and 8) and $105 \mathrm{~g}$ (treatments 3, 6 and 9) (Table 1).

Feedstuffs and feed samples were analyzed for dry matter, ash, crude protein, calcium and phosphorus levels (Table 2). The daily intake per bird of each nutrient of the experimental diets was estimated (Table 3).

Eggs from each replicate were collected daily and counted to determine egg production, and feed residues were weighed once weekly to determine feed intake. An experimental period of 20 weeks was considered for the analyses of the results.
Table 1 - Experimental treatments

\begin{tabular}{lccc}
\hline Treatments & $\begin{array}{c}\text { Energy intake, } \\
\text { hen/day (kcal) }\end{array}$ & $\begin{array}{c}\text { Oil intake, } \\
\text { hen/day }(\mathrm{g})\end{array}$ & $\begin{array}{c}\text { Feed intake, } \\
\text { hen/day }(\mathrm{g})\end{array}$ \\
\hline 1 & 320 & 0.00 & 115 \\
2 & 300 & 0.00 & 110 \\
3 & 280 & 0.00 & 105 \\
4 & 320 & 0.75 & 115 \\
5 & 300 & 0.75 & 110 \\
6 & 280 & 0.75 & 105 \\
7 & 320 & 1.50 & 115 \\
8 & 300 & 1.50 & 110 \\
9 & 280 & 1.50 & 105 \\
\hline
\end{tabular}

Average house temperature and relative humidity recorded during the experimental period were $22.8^{\circ} \mathrm{C}$ and $74 \%$, respectively.

The following parameters were evaluated: initial body weight, final body weight, weight gain, egg production, egg mass, feed conversion ratio per dozen eggs and per egg mass and energy conversion per egg mass.

The data obtained were analyzed using the command General Linear Models of statistical package SAS $^{\circledR}$ (Statistical Analysis System, version 9.1). Parameters presenting normal distribution were subjected to analysis of variance, and when applicable, to orthogonal polynomial regression analysis.

Table 2 - Ingredients and calculated composition of the experimental diets

\begin{tabular}{|c|c|c|c|c|c|c|c|c|c|}
\hline \multirow{2}{*}{$\frac{\text { Ingredients }}{(\%)}$} & \multicolumn{9}{|c|}{ Treatments } \\
\hline & 1 & 2 & 3 & 4 & 5 & 6 & 7 & 8 & 9 \\
\hline Ground corn & 66.48 & 62.98 & 59.23 & 64.09 & 60.45 & 56.58 & 60.67 & 57.92 & 53.93 \\
\hline Soybean meal & 17.27 & 19.10 & 20.96 & 16.90 & 18.76 & 20.63 & 17.57 & 18.45 & 20.24 \\
\hline Wheat bran & 3.50 & 4.58 & 5.86 & 5.66 & 6.83 & 8.17 & 7.74 & 9.02 & 10.47 \\
\hline Meat meal & 2.60 & 2.75 & 2.85 & 2.60 & 2.72 & 2.85 & 2.63 & 2.72 & 2.85 \\
\hline Soybean oil & - & - & - & 0.65 & 0.68 & 0.71 & 1.33 & 1.36 & 1.44 \\
\hline Limestone & 8.84 & 9.24 & 9.65 & 8.87 & 9.28 & 9.69 & 8.90 & 9.32 & 9.74 \\
\hline Dicalcium phosphate & 0.69 & 0.71 & 0.78 & 0.62 & 0.64 & 0.70 & 0.55 & 0.56 & 0.65 \\
\hline Min/vit supplement ${ }^{1}$ & 0.26 & 0.27 & 0.28 & 0.25 & 0.27 & 0.28 & 0.25 & 0.27 & 0.28 \\
\hline Salt & 0.26 & 0.27 & 0.28 & 0.26 & 0.27 & 0.28 & 0.26 & 0.27 & 0.28 \\
\hline Antioxidant & 0.01 & 0.01 & 0.01 & 0.01 & 0.01 & 0.01 & 0.01 & 0.01 & 0.01 \\
\hline DL-methionine & 0.09 & 0.09 & 0.10 & 0.09 & 0.09 & 0.10 & 0.09 & 0.10 & 0.11 \\
\hline Total & 100.0 & 100.0 & 100.0 & 100.0 & 100.0 & 100.0 & 100.0 & 100.0 & 100.0 \\
\hline \multicolumn{10}{|c|}{ Composition } \\
\hline $\mathrm{ME}(\mathrm{kcal} / \mathrm{kg})$ & 2,782 & 2,727 & 2,667 & 2,782 & 2,727 & 2,667 & 2,782 & 2,727 & 2,667 \\
\hline Crude protein $(\%)$ & 15.65 & 16.36 & 17.14 & 15.65 & 16.36 & 17.14 & 15.65 & 16.36 & 17.14 \\
\hline Calcium (\%) & 3.65 & 3.82 & 4.00 & 3.65 & 3.82 & 4.00 & 3.65 & 3.82 & 4.00 \\
\hline Available phosphorus (\%) & 0.36 & 0.36 & 0.38 & 0.36 & 0.36 & 0.38 & 0.36 & 0.36 & 0.38 \\
\hline Methionine (\%) & 0.35 & 0.36 & 0.38 & 0.35 & 0.36 & 0.38 & 0.35 & 0.36 & 0.38 \\
\hline Methionine+cystine (\%) & 0.63 & 0.65 & 0.68 & 0.63 & 0.64 & 0.68 & 0.63 & 0.65 & 0.67 \\
\hline Lysine (\%) & 0.72 & 0.77 & 0.82 & 0.71 & 0.76 & 0.81 & 0.71 & 0.76 & 0.81 \\
\hline
\end{tabular}


Table 3 - Estimated daily intake of each nutrient

\begin{tabular}{lccccccccc}
\hline \multirow{2}{*}{ Nutrients } & \multicolumn{1}{c}{ Treatments } \\
\cline { 2 - 9 } & 1 & 2 & 3 & 4 & 5 & 6 & 7 & 8 \\
\hline ME (kcal/kg feed) & 320 & 300 & 280 & 320 & 300 & 280 & 320 & 300 & 280 \\
Oil intake (g/day) & 0.00 & 0.00 & 0.00 & 0.75 & 0.75 & 0.75 & 1.5 & 1.5 & 1.5 \\
Crude Protein (g/day) & 18.00 & 18.00 & 18.00 & 18.00 & 18.00 & 18.00 & 18.00 & 18.00 & 18.00 \\
Calcium (g/day) & 4.20 & 4.20 & 4.20 & 4.20 & 4.20 & 4.20 & 4.20 & 4.20 & 4.20 \\
Avail. Phosphorus (g/day) & 0.41 & 0.40 & 0.40 & 0.41 & 0.40 & 0.40 & 0.41 & 0.40 & 0.40 \\
Methionine (g/day) & 0.40 & 0.40 & 0.40 & 0.40 & 0.40 & 0.40 & 0.40 & 0.40 & 0.40 \\
Met + cys (g/day) & 0.73 & 0.72 & 0.71 & 0.72 & 0.70 & 0.71 & 0.72 & 0.71 & 0.71 \\
Lysine (g/day) & 0.83 & 0.85 & 0.86 & 0.82 & 0.84 & 0.85 & 0.81 & 0.83 & 0.85 \\
Supp. (g/day) & 0.30 & 0.30 & 0.30 & 0.30 & 0.30 & 0.30 & 0.30 & 0.30 & 0.30 \\
Salt (g/day) & 0.30 & 0.30 & 0.30 & 0.30 & 0.30 & 0.30 & 0.30 & 0.30 & 0.30 \\
\hline
\end{tabular}

ME - metabolizable energy.

\section{Results and Discussion}

There was no interaction between soybean oil and energy intake for any of the parameters evaluated, which shows that the main factors did not interfere with each other, and therefore, their effects were studied separately.

No significant differences in initial body weight were observed. There was no effect of oil intake on any of the parameters evaluated (Table 4). Daily energy intake significantly influenced both final weight and body weight change, which improved as the energy intake increased.

When the regression equations for final weight and body weight change are applied, a significant increasing linear effect linear is observed, as shown below:

$\mathrm{Y}=2.7313 \mathrm{X}+1141, \mathrm{R}^{2}=0.8685$, in which: $\mathrm{Y}=$ final weight and $\mathrm{X}=\mathrm{ME}$ intake.

$\mathrm{Y}=2.6235 \mathrm{X}-816.88, \mathrm{R}^{2}=0.7418$, in which: $\mathrm{Y}=$ body weight change and $\mathrm{X}=\mathrm{ME}$ intake.

These results are consistent with the findings of Lewis et al. (1994), who fed layer diets containing 2600 or $3080 \mathrm{kcal}$
$\mathrm{ME} / \mathrm{kg}$ feed and observed an increase in body weight gain during laying as the dietary energy level increased.

The higher final body weight resulting from the increase in dietary ME was also obtained by Attia et al. (1995), Rosa et al. (1997) and Xavier \& Peixoto (1997), who fed layers with diets with increasing ME levels and concluded that increasing the dietary energy density increases body weight. On the other hand, Araújo \& Peixoto (2005), as well as Jalal et al. (2006), did not find any significant differences in the body weight of young layers (20 to 35 weeks of age) fed increasing metabolizable energy levels.

The results obtained in the present experiment with dietary oil addition are consistent with those of Shafey et al. (1992), who fed three different layer strains with diets with the same amount of calories, containing different cereals and with or without the addition of $2 \%$ of soybean oil, and did not find any significant effect $(\mathrm{P}>0.05)$ on body weight gain.

On the other hand, Keshavarz \& Nakajima (1995) fed layers with diets supplemented with animal fat, corn oil or

Table 4 - Initial body weight, final body weight and weight change of hens subjected to the experimental treatments

\begin{tabular}{|c|c|c|c|c|c|c|}
\hline \multirow{2}{*}{ Parameters } & \multirow{2}{*}{$\begin{array}{l}\text { Oil intake } \\
\text { (g/hen/day) }\end{array}$} & \multicolumn{3}{|c|}{ Energy intake (kcal/hen/day) } & \multirow{2}{*}{ Mean } & \multirow{2}{*}{$\mathrm{CV}(\%)$} \\
\hline & & 280 & 300 & 320 & & \\
\hline \multirow{3}{*}{ Initial weight (g) } & 0.00 & 1992 & 2002 & 1990 & 1995 & \\
\hline & 0.75 & 1963 & 2006 & 1988 & 1986 & 2.90 \\
\hline & Mean & 1982 & 2001 & 1986 & & \\
\hline \multirow[t]{2}{*}{ Final weight $(\mathrm{g})^{1}$} & 0.00 & 1927 & 1933 & 2055 & 1971 & \\
\hline & Mean & 1918 & 1936 & 2027 & & \\
\hline \multirow[t]{4}{*}{ Weight change $(\mathrm{g})^{1}$} & 0.00 & -64.55 & -69.17 & 64.42 & -23.10 & \\
\hline & 0.75 & -63.58 & -64.35 & 24.35 & -34.53 & 2.62 \\
\hline & 1.50 & -65.12 & -63.15 & 32.80 & -31.83 & \\
\hline & Mean & -64.42 & -65.56 & 40.52 & & \\
\hline
\end{tabular}

${ }^{1}$ Significant linear effect $(\mathrm{P}<0.05)$ for daily metabolizable energy intake.

$\mathrm{CV}$ - coefficient of variation. 
a mixture of both at levels of 0,2 and $4 \%$ and concluded that weight gain between 18-38 weeks was significantly influenced by fat addition, with those fed the oil-fat mixture presenting higher weight gain than those fed $2 \%$ animal fat. Grobas et al. (1997) also studied the effect of dietary fat supplementation and different energy levels in layer diets, and concluded that high energy and fat diets increase energy intake and body weight.

There was no influence of the treatments on egg production (Table 5). Similar results were also obtained by Costa et al. (2004), Wu et al. (2007), Jalal et al. (2007) and Costa et al. (2009), who fed layers with different ME levels and concluded that the dietary energy level did not cause any significant effect $(\mathrm{P}>0.05)$ on egg production. However, Araújo \& Peixoto (2005) observed instead a reduction in egg production $(\mathrm{P}<0.05)$ as the dietary energy level increased, whereas Valkonen et al. (2008) obtained an increase in egg production with increasing dietary energy levels; however, the latter worked with energy levels lower than those used in the present study and those recommended in the literature (2345 to $2629 \mathrm{kcal} \mathrm{ME} / \mathrm{kg}$ feed). These controversial results may be explained by the fact the energy levels higher than those recommended do not increase production, while energy deficiency decreases production.

There was no influence of energy and oil levels on egg mass, as previously observed by Jalal et al. (2007),
Valkonen et al. (2008) and Costa et al. (2009), who fed layers with diets containing different energy levels and also did not find any effect on egg mass. However, Wu et al. (2007) observed an increase in egg mass as the dietary ME level increased.

In relation to the addition of oil to the feed, the results of the present study are consistent with those of Costa et al. (2009), who compared diets with the inclusion of 1, 2 and $3 \%$ soybean oil and concluded that there was no significant effect of the treatments on egg mass. Parsons et al. (1993) fed layers with diets containing different protein levels and the addition of $0,2,4$ or $6 \%$ corn oil and obtained significantly higher $(\mathrm{P}<0.05)$ egg production and egg mass with the addition of oil to the diet. This may be explained by the possible dietary deficiency of essential fatty acids, which were supplemented by the addition of oil to the diet, with consequent improvement of egg weight, and hence, egg mass.

Feed conversion ratio per egg weight $(\mathrm{FCR} / \mathrm{kg})$ and per dozen eggs $(\mathrm{FCR} / \mathrm{dz})$ were significantly impaired $(\mathrm{P}<0.05)$ as the energy intake increased. Treatments presented an increasing linear effect $(\mathrm{P}<0.05)$ on these parameters, and are expressed in the following equations $\mathrm{Y}=0.0034 \mathrm{X}+$ $1.2231, \mathrm{R}^{2}=0.9996$, in which $\mathrm{Y}=$ feed conversion ratio/ mass and $\mathrm{X}=$ energy intake for $\mathrm{FCR} / \mathrm{kg}$, and $\mathrm{Y}=0.0036 \mathrm{X}+$ $0.5671, \mathrm{R}^{2}=0.9972$, in which $\mathrm{Y}=$ feed conversion ratio per

Table 5 - Egg production, egg mass, feed conversion ratio/kg eggs (FCR/kg), feed conversion ratio/dozen eggs (FCR/dz) and energy conversion $/ \mathrm{kg}$ eggs $(\mathrm{EC} / \mathrm{kg})$ of hens subjected to the experimental treatments

\begin{tabular}{|c|c|c|c|c|c|c|}
\hline \multirow{2}{*}{ Parameters } & \multirow{2}{*}{$\begin{array}{l}\text { Oil intake } \\
\text { (g/hen/day) }\end{array}$} & \multicolumn{3}{|c|}{ Energy intake (kcal/hen/day) } & \multirow{2}{*}{ Mean } & \multirow{2}{*}{$\mathrm{CV}(\%)$} \\
\hline & & 280 & 300 & 320 & & \\
\hline \multirow[t]{4}{*}{ Egg production (\%) } & 0.00 & 81.38 & 81.24 & 81.22 & 81.28 & \\
\hline & 0.75 & 80.84 & 82.86 & 87.15 & 83.65 & 4.30 \\
\hline & 1.50 & 82.78 & 83.06 & 82.38 & 82.74 & \\
\hline & Mean & 81.70 & 82.38 & 83.58 & & \\
\hline \multirow[t]{4}{*}{ Egg mass (g/hen/day) } & 0.00 & 49.32 & 49.64 & 47.67 & 48.88 & \\
\hline & 0.75 & 48.36 & 48.89 & 53.12 & 50.12 & 5.17 \\
\hline & 1.50 & 48.96 & 50.06 & 50.32 & 49.78 & \\
\hline & Mean & 48.88 & 49.53 & 50.37 & & \\
\hline \multirow[t]{4}{*}{$\mathrm{FCR} / \mathrm{kg}^{1}$} & 0.00 & 2.16 & 2.22 & 2.43 & 2.27 & \\
\hline & 0.75 & 2.18 & 2.27 & 2.18 & 2.21 & 5.36 \\
\hline & 1.50 & 2.16 & 2.21 & 2.29 & 2.22 & \\
\hline & Mean & 2.16 & 2.23 & 2.30 & & \\
\hline \multirow[t]{4}{*}{$\mathrm{FCR} / \mathrm{dz}$} & 0.00 & 1.57 & 1.63 & 1.71 & 1.63 & \\
\hline & 0.75 & 1.56 & 1.60 & 1.59 & 1.59 & 4.41 \\
\hline & 1.50 & 1.53 & 1.60 & 1.68 & 1.60 & \\
\hline & Mean & 1.55 & 1.61 & 1.66 & & \\
\hline \multirow[t]{4}{*}{$\mathrm{EC} / \mathrm{kg}^{1}$} & 0.00 & 5.80 & 6.06 & 6.76 & 6.20 & \\
\hline & 0.75 & 5.81 & 6.20 & 6.06 & 6.02 & 5.41 \\
\hline & 1.50 & 5.75 & 6.01 & 6.38 & 6.04 & \\
\hline & Mean & 5.79 & 6.09 & 6.40 & & \\
\hline
\end{tabular}

${ }^{1}$ Significant linear effect $(\mathrm{P}<0.05)$ for daily metabolizable energy intake.

$\mathrm{CV}$ - coefficient of variation, 
dozen eggs and $\mathrm{X}=$ energy intake for $\mathrm{FCR} / \mathrm{dz}$. This may be explained by the higher feed intake of the birds fed higher energy levels, according to the experimental treatments.

The results of the present experiment disagree with the findings of Grobas et al. (1999), Wu et al. (2007) and Valkonen et al. (2008), who fed layers different dietary ME levels and observed an improvement $(\mathrm{P}<0.05)$ in feed conversion ratio as the dietary $\mathrm{ME}$ increased. On the other hand, Grobas et al. (1999) and Costa et al. (2004) evaluated the effect of the intake of feeds containing different energy levels on the egg production of layers and concluded that feed conversion ratio was not influenced $(\mathrm{P}>0.05)$ by the dietary energy level; however, feed was offered ad libitum in these experiments. The differences in feed conversion ratio results per $\mathrm{kg}$ and per dozen eggs may be due to the energy levels used in the different studies because, when energy supply is higher than the nutritional requirements of birds, there are no improvements in egg production, egg mass or feed conversion ratio; however, the energy surplus may be stored in the body, increasing body weight and body fat content. The study of Costa et al. (2009) must also be mentioned; the authors worked with three energy levels (2600, 2750 and $2900 \mathrm{kcal} \mathrm{ME})$ and a feed intake limited to $120 \mathrm{~g} / \mathrm{bird} /$ day and did not find any effect on feed conversion ratio, which may be a result of establishing the same feed intake for the different energy levels.

No effects of addition of oil to the diet on feed conversion ratio per dozen eggs or per egg mass were observed. These results are in agreement with those of Kling \& Hawes (1990), Reddy et al. (1991) and Costa et al. (2009), who compared feeds with different oil levels and concluded that oil inclusion did not influence feed conversion ratio.

Energy conversion per $\mathrm{kg}$ eggs worsened $(\mathrm{P}<0.05)$ as a function of daily energy intake, with an increasing linear effect, as shown by the equation: $\mathrm{Y}=0.024 \mathrm{X}-0.9947$, in which: $\mathrm{Y}=$ energy conversion and $\mathrm{X}=$ energy intake, with $\mathrm{R}^{2}=0.9371$. These results indicate that the energy intake of $280 \mathrm{kcal} / \mathrm{bird} /$ day supplied the energy requirements for maintenance and production of the experimental birds. Araújo \& Peixoto (2005) and Costa et al. (2009) also found a significant linear effect on energy conversion, which worsened as the dietary energy level increased. Conflicting results were observed by Jalal et al. (2006) and Valkonen et al. (2008), who did not find any significant difference in energy conversion. No effect of oil addition on energy conversion per kg eggs was detected, which was also found by Costa et al. (2009) when feeding different oil levels to brown layers. No influence of the dietary inclusion of up to $3 \%$ oil on energy conversion per dozen eggs and per egg mass was found.

\section{Conclusions}

Under the conditions of the present study, and according to the results obtained, the dietary energy level of $280 \mathrm{kcal} /$ bird/day with no oil addition may be used for brown layers with no effect on their performance.

\section{References}

ARAÚJO, J.S.; PEIXOTO, R.R. Níveis de energia metabolizável em rações para poedeiras de ovos marrons nas condições de inverno no extremo sul do Brasil. Archivos de Zootecnia, v.54, p.13-23, 2005.

ATTIA, Y.A.; BURKE, W.H.; YAMANI, K.A. et al. Daily energy alloments and performance of broiler breeders. 2. females. Poultry Science, v.74, p.261-70, 1995.

COSTA, F.G.P.; SOUZA, H.C.; GOMES, C.A.V. et al. Níveis de proteína bruta e energia metabolizável na produção e qualidade dos ovos de poedeiras da linhagem Lohmann Brown. Ciência Agrotécnica, v.28, n.6, p.1421-1427, 2004.

COSTA, F.G.P.; QUIRINO, B.J.S.; GIVISIEZ, P.E.N. et al. Poedeiras alimentadas com diferentes níveis de energia e óleo de soja na ração. Archivos de Zootecnia, v.58, n.223, p.405-41, 2009.

FARIA, D.E.; SILVA, F.H.A. Avanços recentes na nutrição de poedeiras durante a fase de produção. In: CONFERÊNCIA APINCO DE CIÊNCIA E TECNOLOGIA AVÍCOLAS, 14., Santos, 1993. Anais... Santos: Apinco, 2004. v.2, p.31-43.

GROBAS, S.; MENDEZ, J.; BLAS, C. et al. Laying hen productivity as affected by energy, supplemental fat, and linoleic acid concentration of the diet. Poultry Science, v.78, p.1542-1551, 1999.

GROBAS, S.; MENDES, J.; MEDEL, P. et al. Influence of energy, linoleic acid and fat content of the diet on performance and weight of egg components of brown layers. Poultry Science, v.76, p.256, 1997.

HARMS, R.H.; RUSSEL, G.B.; SLOAN, D.R. Performance of four strains of commercial layers with major changes in dietary energy. Journal of Applied Poultry Research, v.9, p.535-41, 2000.

JALAL, M.A.; SCHEIDELER, S.E.; MARX, D. Effect of bird cage space and dietary metabolizable energy level on production parameters in laying hens. Poultry Science, v.8, p.306-311, 2006.

JALAL, M.A.; SCHEIDELER, S.E.; PIERSON, E.M. Strain response of laying hens to varying dietary energy levels with and without avizyme supplementation. Journal of Applied Poultry Research, v.16, p.289-295, 2007.

KESHAVARZ, K.; NAKAJIMA, S. The effect of dietary manipulations of energy, protein, and fat during the growing and laying periods on early egg weight and egg components. Poultry Science, v.74, p.50-61, 1995.

KLING, L.J.; HAWES, R.O. Effect of fat, protein and methionine concentrations on egg size and production in early maturated brown-egg-type pullets. Poultry Science, v.69, p.1943-49, 1990.

LEWIS, P.D.; MacLEOD, M.G.; PERRY, G.C. Effects of lighting regimen and grower diet energy concentration on energy expenditure, fat deposition and body weight gain of laying hens. British Poultry Science, v.35, p.407-15, 1994.

MOURA, B.H.S.; BAIÃO, N.C.; LÓPEZ, C.A.A. et al. Efeito do nível de energia e do óleo sobre a composição da carcaça de frangos de corte. In: CONFERÊNCIA APINCO DE CIÊNCIA E TECNOLOGIAAVÍCOLAS, 24., Santos, 2003. Anais... Campinas: Apinco, 2003. p.45.

MURAMATSU, K.; SRINGHINI, J.H.; CAFÉ, M.B. et al. Influência de rações à base de milho e milheto, formuladas com diferentes níveis de óleo vegetal na qualidade do ovo e no desempenho produtivo de poedeiras comerciais (resultados parciais). In: CONGRESSO DE PRODUÇÃO E CONSUMO DE OVOS, 2., São Paulo, 2000. Anais... São Paulo: APA, 2000. p.201-202. 
PARSONS, C.M.; KOELKEBECK, K.W.; ZHANG, Y. et al. Effect of dietary protein and added fat levels on performance of young laying hens. Journal of Apllied Poultry Research, v.2, p.214-20, 1993.

PENZ JÚNIOR, A.M.; PAVAN, A.C. Controle de qualidade de ingredientes e de processos na produção de rações. In: CONGRESSO DE PRODUÇÃO, COMERCIALIZAÇÃO E CONSUMO DE OVOS, 5., Indaiatuba, 2007. Anais... Indaiatuba: Associação Paulista de Avicultura, 2007. p.129-137

PINTO, A.L.; RABELLO C.B.V.; RIBEIRO H.U. et al. Influência do nível de óleo na ração sobre os custos na produção de ovos de poedeiras comerciais criadas em regiões de alta temperatura. In: CONFERÊNCIA APINCO DE CIÊNCIA E TECNOLOGIA AVÍCOLAS, 23., Campinas, 2002. Anais... Campinas: Apinco, 2002. p.34.

REDDY, R.V.; LIGHTSEY, S.F.; MAURICE, D.V. Research note: effect of feeding garlic oil on performance and egg yolk cholesterol concetration. Poultry Science, v.70, p.2006-2009, 1991.

ROSA, A.P.; ZANELLA, I.; THIER. J. et al. Influência de diferentes níveis de proteína bruta e energia metabolizável no desempenho de fêmeas Plymouth Rock Barrada na fase de recria. Revista Brasileira de Zootecnia, v.26, n.1, p.153-58, 1997.

SHAFEY, T.M.; DINGLE, J.G.; McDONALD, M.W. Comparation between wheat, triticale, rye, soybean oil and strain of laying bird on the production, and cholesterol and fatty acid contents of eggs. British Poultry Science, v.33, p.339-46, 1992.

TARDIN, A.C. Conceituação e importância da energia na nutrição de aves. In: CONFERÊNCIAAPINCO DE CIÊNCIAETECNOLOGIA AVÍCOLAS, 16., Curitiba, 1995. Anais... Curitiba: Apinco, 1995. p.213-39.

VALKONEN, E.; VENALAINEN, E.; ROSSOW, L. et al. Effects of dietary energy content on the performance of laying hens in furnished and conventional cages. Poultry Science, v.87, p.844-852, 2008.

XAVIER, E.G.; PEIXOTO, R.R. Nível de energia metabolizável em rações para poedeiras nas condições de temperatura e umidade relativa no inverno do extremo sul do Brasil. Revista Brasileira de Zootecnia, v.26, n.2, p.364-74, 1997.

WU, G.; BRYANT, M.M.; GUNAWARDANA, P. et al. Effect of nutrient density on performance, egg components, egg solids, egg quality, and profits in eight commercial Leghorn strain during phase one. Poultry Science, v.86, p.691-697, 2007. 